\title{
ЗМІНИ ПОКАЗНИКІВ КАЛІКРЕЇН-КІНІНОВОЇ СИСТЕМИ У ХВОРИХ НА ХРОНІЧНИЙ ПАНКРЕАТИТ ІЗ СУПУТНІМ ЦУКРОВИМ ДІАБЕТОМ
}

\section{๑У. М. Захарчук, Л. С. Бабінець, С. Р. Підручна \\ ДВНЗ «Тернопільський державний медичний університет імені І. Я. Горбачевського МОЗ України»}

РЕЗЮМЕ. Калікреїн-кінінова система відіграє важливу роль у перебігу хронічного панкреатиту, поєднаного із супутнім цукровим діабетом.

Метою роботи було дослідити вплив наявності цукрового діабету на показники калікреїн-кінінової системи у хворих на хронічний панкреатит.

Матеріал і методи. Обстежено 112 хворих на ХП, яких було поділено на 2 групи: I група - 35 хворих на ХП без ЦД; II група - 77 хворих на ХП із супутнім ЦД.

Результати. Виявлено статистично достовірно більш значиму активацію ПРА, підвищення протеолітичного ферменту КК, зниження рівня ПКК, підвищення рівнів $\mathrm{a}_{1}$-ІП та $\mathrm{a}_{2}$-МГ та зниження активності кінінази-ІІ у хворих на хронічний панкреатит із супутнім цукровим діабетом $(p<0,05)$, порівняно з хворими на ХП без ЦД.

Висновки. Вищезазначене свідчить про ускладнювальну роль розладу калікреїн-кінінової системи при коморбідному перебігу хронічного панкреатиту і цукрового діабету.

КлючОВІ СлОВА: хронічний панкреатит; цукровий діабет; калікреїн-кінінова система.

Вступ. Незважаючи на достатню кількість досліджень вітчизняних і зарубіжних вчених, дотепер залишаються не до кінця з'ясованими численні питання складного патогенезу у хворих на хронічний панкреатит (ХП) із супутнім цукровим діабетом (ЦД). Зокрема, не вивчений стан калікреїн-кінінової системи (ККС) у хворих з поєднаною патологією підшлункової залози (ПЗ), хоча відомо, що оцінка змін кініногенезу об'єктивно відображає активність запальної реакції, стан мікроциркуляції, дозволяє спрогнозувати перебіг захворювання.

ККС $€$ центральною ланкою в комплексі гуморальних систем, які регулюють гомеостаз і здійснюють адаптивно-захисні реакції. Кініни крові і міжтканинної рідини виконують роль медіаторів усіх життєво важливих фізіологічних і біохімічних процесів. Це зумовлено тим, що ККС тісно пов'язана із діяльністю чотирьох гуморальних систем: згортальної, імунної, фібринолітичної, ренін-ангіотензинової. Біохімічним посередником цих систем $\epsilon$ калікреїн (КК). Теоретичний і практичний інтерес викликає вивчення взаємозв'язку між функціональним станом ККС та функціонуванням ПЗ, в якій виявляються активні компоненти КKС $[1,4]$.

При концентраціях у крові в сотні разів менших, ніж інших біологічно активних речовин (серотонін і гістамін), кініни визначають стан мікроциркуляції, моторної і секреторної функції органів, зокрема, ПЗ. Роль ККС визначається концентрацією і співвідношенням їі компонентів, які в різних умовах можуть бути факторами захисту або альтерації. Стан ККС визначається трьома основними процесами: кініноутворенням (при збільшенні рівня загального, вільного і зв'язаного
3 інгібіторами калікреїну), кініноруйнуванням (зміною активності кінінази) та інгібуванням кініногенезу. Дефіцит кініназ призведе до пролонгованої дії кінінів і їх накопичення у крові.

Клінічне значення мають фаза зміни кініногенезу: або активація (посилення), або послаблення, а також якісні зміни співвідношення компонентів КKC $[2,6,7]$. У невеликих концентраціях кініни $\epsilon$ регуляторами робочої гіперемії органів, що забезпечує їх нормальне функціонування. Високі концентрації KK і зниження кініногену в крові відображають початок деструктивного процесу. У хворих на ХП співвідношення компонентів ККС змінюється і адаптація ККС стає фактором пошкодження. Патогенез ХП пов'язують із зміною обміну кінінів. Особливо цікавим і практично не вивченим залишається питання стану і ролі ККС при ХП у поєднанні з ЦД, що робить дане дослідження актуальним.

Метою дослідження було дослідити зміни показників калікреїн-кінінової системи у хворих на хронічний панкреатит із супутнім цукровим діабетом.

Матеріал і методи дослідження. Обстежено 112 хворих на ХП, які перебували на диспансерному обліку в центрі первинної медико-санітарної допомоги м. Тернополя та у гастроентерологічному відділенні Тернопільської міської клінічної лікарні № 2. Групу порівняння склали 20 здорових осіб, які не мали жодних скарг з боку шлунково-кишкового тракту (ШКТ).

Джерелом інформації для клініко-анамнестичного аналізу слугували «Медичні карти амбулаторного хворого» (ф. 025/о) і «Медичні карти стаціонарного хворого» ( $\$ .003 / 0)$ досліджуваних пацієнтів з ХП протягом 2013-2017рр. Усіх 112 па- 
Огляди літератури, оригінальні дослідження, погляд на проблему

цієнтів було поділено на 2 групи: I група - 35 хворих на ХП без ЦД; II група - 77 хворих на ХП із супутнім ЦД. Групу контролю склали 20 практично здорових осіб.

Вік пацієнтів коливався від 20 до 65 років. Середній вік хворих на ХП становив $(46,31 \pm 1,71)$ років, а хворих на ХП з ЦД - $(52,86 \pm 0,83)$ років.

Середня тривалість захворювання у групі хворих на ХП становила $(7,03 \pm 0,64)$ років, а у групі хворих на ХП з ЦД- $(10,96 \pm 0,39)$ років.

Діагноз ХП верифікували на підставі даних анамнезу, клінічних проявів - наявності больового, диспептичного, астено-вегетативного, ентеропанкреатичного синдромів, зовнішньосекреторної та внутрішньосекреторної недостатності; діагноз ЦД - на підставі анамнезу, клінічних проявів - гіперглікемічного синдрому, даних лабораторних обстежень [3, 5]. Основне завдання здійснено шляхом дослідження параметрів загального i специфічного протеолізу з використанням сучасних методів їх визначення. Визначали загальну протеолітичну активність (ПРА) плазми за гідролізу протамін сульфату, вміст КК плазми - за допомогою хромогенного пептидного субстрату хромозиму РК, прекалікреїну (ПКК), $a_{1}$ інгібітор

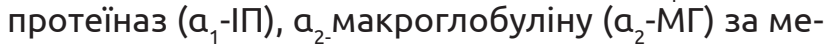
тодом К. М. Веремеєнко. Отримані дані були статистично опрацьовані за допомогою програм «Microsoft Excel» та «Statistica 6.0». Обчислювали середні арифметичні величини (М) з середньою квадратичною похибкою (m). Перевірку гіпотез про достовірність різниці двох середніх (р) виконували за допомогою U-критерію Манна-Уїтні. Результати вважали достовірними при рівні їх статистичної значимості $\mathrm{p}<0,05$.

Результати й обговорення. При дослідженні загального та специфічного протеолізу ми отримали результати, наведені у таблиці 1.
Було встановлено статистично достовірно вищий рівень активації загального протеолізу за рівнем ПРА у хворих на ХП і ЦД $(41,78 \pm 1,55)$, порівняно з групою хворих на ХП $(36,24 \pm 1,10)$ і групою контролю $(30,95 \pm 0,92)$. Було відмічено підвищення специфічного протеолізу, або кініногенезу, за рівнем ферменту протеолізу КК, який мав аналогічну з ПРА тенденцію у хворих на ХПі ЦД. Було виявлено зниження неактивного попередника КК - ПКК, рівень якого був зниженим у II групі хворих $(52,70 \pm 0,99)$, порівняно 3 І групою $(64,89 \pm 0,73)$ та групою контролю $(75,30 \pm 1,31)$. Контроль за активністю протеолізу здійснює $\mathrm{a}_{1}-$-П, рівень якого був збільшений у хворих на ХП і ЦД $(1,81 \pm 0,04)$, порівняно з групою хворих на ХП $(1,64 \pm 0,02)$ і групою контролю $(1,49 \pm 0,01)$. $\mathrm{a}_{2}$-МГ у групі хворих на ХП $(1,13 \pm 0,02)$ був знижений відносно контролю $(1,44 \pm 0,04)$, а у групі хворих на ХП і ЦД він був підвищений $(1,81 \pm 0,09)$. Встановлено зниження активності кінінази-ІІ у хворих на ХП $(199,76 \pm 4,41)$ та ХП з ЦД $(173,78 \pm 3,14)$, порівняно $з$ контролем $(258,37 \pm 5,88)$, що вказує на ослаблення захисних реакцій організму внаслідок надмірної продукції кінінів.

Висновки. Виявлено статистично достовірно більш значиму активацію ПРА, підвищення протеолітичного ферменту КK, зниження рівня ПКК, підвищення рівнів $\mathrm{a}_{1}-$ ІІ та $\mathrm{a}_{2}$-МГ та зниження активності кінінази-ІІ у хворих на хронічний панкреатит із супутнім цукровим діабетом $(p<0,05)$, порівняно з хворими на хронічний панкреатит без цукрового діабету. Це констатувало ускладнювальну роль розладу калікреїн-кінінової системи при наявності коморбідного перебігу хронічного панкреатиту і цукрового діабету, що необхідно враховувати при обиранні лікувальної тактики.

У перспективі подальших досліджень плануємо визначити зміни показників ККС під впливом різних програм лікування.

Таблиця 1. Показники загального та специфічного протеолізу у групах обстежених хворих на ХП залежно від наявності ЦД

\begin{tabular}{|l|c|c|c|}
\hline \multirow{2}{*}{\multicolumn{2}{|c|}{ Показник протеолізу }} & \multicolumn{3}{|c|}{ Група порівняння } \\
\cline { 2 - 4 } & $\begin{array}{c}\text { контрольна група } \\
(\mathrm{n}=20)\end{array}$ & $\begin{array}{c}\text { хворі на ХП } \\
(\mathrm{n}=35)\end{array}$ & $\begin{array}{c}\text { хворі на ХП і ЦД } \\
(\mathrm{n}=77)\end{array}$ \\
\hline ПРА, ммоль аргініну/(год.л) & $30,95 \pm 0,92$ & $36,24 \pm 1,10^{*}$ & $41,78 \pm 1,55^{* *}$ \\
\hline КК, мКмоль/(хв.л) & $53,22 \pm 2,42$ & $117,62 \pm 5,73^{*}$ & $175,72 \pm 6,90 * *$ \\
\hline ПКК, мКмоль/(хв.л) & $75,30 \pm 1,31$ & $64,89 \pm 0,73^{*}$ & $52,70 \pm 0,99 * *$ \\
\hline $\mathrm{a}_{1}$-ІП, г/л & $1,49 \pm 0,01$ & $1,64 \pm 0,02 *$ & $1,81 \pm 0,04 * *$ \\
\hline $\mathrm{a}_{2}$-МГ, г/л & $1,44 \pm 0,04$ & $1,13 \pm 0,02 *$ & $1,81 \pm 0,09 * *$ \\
\hline Активність кінінази-ІІ, мкмоль ГК/(хв.л) & $258,37 \pm 5,88$ & $199,76 \pm 4,41^{*}$ & $173,78 \pm 3,14 * *$ \\
\hline
\end{tabular}

Примітки:

1. * достовірність різниці показників хворих на ХП І групи стосовно таких групи контролю $\left(p_{1-2}<0,05\right)$;

2. ** - достовірність різниці показників хворих на XП II групи стосовно таких I групи $\left(p_{1-3}<0,05\right)$. 
Огляди літератури, оригінальні дослідження, погляд на проблему

ЛІТЕРАТУРА

1. Бабінець Л. С. Аналіз впливу різних етіологічних чинників на виникнення хронічного панкреатиту / Л. С. Бабінець // Вісник Вінницького держ. мед. університету. - 2003. - № 7 (2/1). - С. 444-445.

2. Губергиц Н. Б. Клическая панкреатология / Н. Б. Губергриц, Т. М. Христич. - Донецк : ООО «Лебедь», 2013. - 236 с.

3. Сучасні класифікації та стандарти лікування розповсюджених захворювань внутрішніх органів / за ред. Ю. М. Мостового. - 11-те вид., доп. і переро6. - Вінниця, 2011. $-511 \mathrm{c}$.

4. The kinin system - bradykinin: biological effects and clinical implications. Multiple role of the kinin system - bradykinin / Ch. Golias, A. Charalabopoulos, D. Stagikas [et al.] // Hippokratia. - 2007. - Vol. 11, № 3. - P. 124-128.

5. Interactions between the endocrine and exocrine pancreas and their clinical relevance / L. Czakó, P Hegyi, Z. Jr. Rakonczay [et al.] // Pancreatology. - 2009. - Vol. 9 , № 4. - P. 351-359.

6. Meier J. J. Functional assessment of pancreatic b-cell area in humans / J. J. Meier, B. A. Menge, T. G. Breuer // Diabetes. - 2009. - P. 595-603.

7. Determinants of glucose control in patients with chronic pancreatitis / H. Schrader, B. A. Menge, C. Zeidler, P. R. Ritter // Diabetologia. - 2010. - P. 43-47.

\title{
REFERENCES
}

1. Babinets, L.S. (2003). Analiz vplyvu riznykh etiolohichnykh chynnykiv na vynyknennia khronichnoho pankreatytu [Analysis of the impact of various etiological factors on the occurrence of chronic pancreatitis]. Visnyk Vinnytskoho derzh. med. Universytetu - Journal of Vinnytsia National Medical University, 7 (2/1), 444-445 [in Ukrainian].

2. Huberhryts, N.B., \& Khrystych, T.M. (2013). Klinicheskaya pankreatologiya [Clinical pancreatology]. Donetsk: OOO «Lebed» [in Russian].

3. Mostovyi, Iu.M. (Ed.) (2011). Suchasni klasyfikatsii ta standarty likuvannia rozpovsiudzhenykh zakhvoriuvan vnutrishnikh orhaniv [Current classification and standarts of treatment of common internal diseases]. Vinnytsia [in Ukrainian].

4. Golias, Ch., Charalabopoulos, A., Stagikas, D., Charalabopoulos, K. \& Batistatou, A. (2007). The kinin system - bradykinin: biological effects and clinical implications. Multiple role of the kinin system - bradykinin. Hippokratia, 11 (3), 124-128.

5. Czakó, L., Hegyi, P., \& Rakonczay, Z.Jr. (2009). Interactions between the endocrine and exocrine pancreas and their clinical relevance. Pancreatology, 9 (4), 351-359.

6. Meier, J.J., Menge, B.A., \& Breuer, T.G. (2009). Functional assessment of pancreatic b-cell area in humans. Diabetes, 58 (7), 1595-1603.

7. Schrader, H., Menge, B.A., Zeidler, C., \& Ritter, P.R. (2010). Determinants of glucose control in patients with chronic pancreatitis. Diabetologia, 53, 1062-1069.

\section{ИЗМЕНЕНИЯ ПОКАЗАТЕЛЕЙ КАЛЛИКРЕИН-КИНИНОВОЙ СИСТЕМЫ У БОЛЬНЫХ ХРОНИЧЕСКИМ ПАНКРЕАТИТОМ С СОПУТСТВУЮЩИМ САХАРНЫМ ДИАБЕТОМ}

\author{
○У. М. Захарчук, Л. С. Бабинец, С. Р. Пидручная
}

ГВУз «Тернопольский государственный медицинский университет имени И. Я. Горбачевского МЗ Украины»

РЕЗЮМЕ. Калликреин-кининовая система играет важную роль в развитии хронического панкреатита с сопутствующим сахарным диабетом.

Целью нашей работы было исследование влияния сахарного диабета на показатели калликреин-кининовой системы у больных хроническим панкреатитом.

Материал и методы. Обследовано 112 больных ХП, которые были поделены на 2 группы: I группа - 35 больных ХП без СД; II группа - 77 больных ХП с сопутствующим СД.

Выводы. Обнаружены статистически достоверная активация ПРА, повышение протеолитического фермента КК, снижение уровня ПКК, повышение уровня $a_{1}$-ИП и $a_{2}-$ МГ и снижение активности кининазы-ІІ у больных ХП с сопутствующим СД $(p<0,05)$ в сравнении с больными ХП без СД. Это констатировало усложняющую роль расстройства калликреин-кининовой системы при наличии коморбидного течения ХП и СД.

КЛЮЧЕВЫЕ СЛОВА: хронический панкреатит, сахарный диабет, калликреин-кининовая система. 
Огляди літератури, оригінальні дослідження, погляд на проблему

THE CHANGES OF INDICATORS OF THE KININ-KALLIKREIN SYSTEM IN PATIENTS WITH CHRONIC PANCREATITIS WITH CONCOMITANT DIABETES MELLITUS

@U. M. Zakharchuk, L. S. Babinets, S. R. Pidruchna

\section{Horbachevsky Ternopil State Medical University}

SUMMARY. The kinin-kallikrein system plays an important role in the course of chronic pancreatitis (CP) with concomitant diabetes mellitus.

The aim of our work was to investigate the effect of diabetes mellitus on the parameters of the kinin-kallikrein system in patients with CP.

Material and Methods. The study involved 112 patients with CP that were divided into 2 groups: I group - 35 patients with CP without diabetes; II group - 77 patients with CP with concomitant diabetes.

Conclusions. A statistically significant activation of proteolytic activity, increase of the proteolytic enzyme of the kallikrein, decrease of the prekallikrein level, increase of the a1-proteinase inhibitor and $a_{2}$-macroglobulin levels and decrease of the kininase-II activity in patients with CP with concomitant diabetes $(p<0.05)$ compared to patients with only CP have been proved. This ascertains a complicating role of injury of kinin-kallikrein system in comorbidity of CP and diabetes.

KEY WORDS: chronic pancreatitis; diabetes mellitus; kinin-kallikrein system. 